\title{
Differential effects of cotreatment of the antibiotic rifampin with host-directed therapeutics in reducing intracellular Staphylococcus aureus infection
}

\author{
Melissa D Evans ${ }^{\text {Corresp., }}{ }^{1}$, Robert Sammelson ${ }^{2}$, Susan McDowell ${ }^{1}$ \\ ${ }^{1}$ Department of Biology, Ball State University, Muncie, Indiana, United States \\ 2 Department of Chemistry, Ball State University, Muncie, Indiana, United States \\ Corresponding Author: Melissa D Evans \\ Email address: melissa.evans96@outlook.com
}

Background. Chronic infection by Staphylococcus aureus drives pathogenesis in important clinical settings, such as recurrent pulmonary infection in cystic fibrosis and relapsing infection in osteomyelitis. Treatment options for intracellular $S$. aureus infection are limited. Rifampin, a lipophilic antibiotic, readily penetrates host cell membranes, yet monotherapy is associated with rapid antibiotic resistance and development of severe adverse events. Antibiotic cotreatment can reduce this progression, yet efficacy diminishes as antibiotic resistance develops. ML141 and simvastatin inhibit S. aureus invasion through host-directed rather than bactericidal mechanisms.

Objective. To determine whether cotreatment of ML141 or of simvastatin with rifampin would enhance rifampin efficacy.

Methods. Assays to assess host cell invasion, host cell viability, host cell membrane permeability, and bactericidal activity were performed using the human embryonic kidney (HEK) 293-A cell line infected with S. aureus (29213) and treated with vehicle control, simvastatin, ML141, rifampin, or cotreatment of simvastatin or ML141 with rifampin.

Results. We found cotreatment of ML141 with rifampin reduced intracellular infection nearly $85 \%$ when compared to the no treatment control. This decrease more than doubled the average $40 \%$ reduction in response to rifampin monotherapy. In contrast, cotreatment of simvastatin with rifampin failed to improve rifampin efficacy. Also, in contrast to ML141, simvastatin increased propidium iodide (PI) positive cells, from an average of $10 \%$ in control HEK 293-A cells to nearly $20 \%$ in simvastatin-treated cells, indicating an increase in host cell membrane permeability. The simvastatin-induced increase was reversed to control levels by cotreatment of simvastatin with rifampin.

Conclusion. Taken together, rifampin efficacy is increased through host-directed inhibition of $S$. aureus invasion by ML141, while efficacy is not increased by simvastatin. Considerations regarding novel therapeutic approaches may be dependent on underlying differences in pharmacology. 
2 Differential effects of cotreatment of the antibiotic

3 rifampin with host-directed therapeutics in reducing

4 intracellular Staphylococcus aureus infection

7 Melissa D. Evans ${ }^{1}$, Robert E. Sammelson ${ }^{2}$, Susan. A McDowell ${ }^{1}$

8

${ }^{1}$ Department of Biology, Ball State University, Muncie, Indiana, United States of America

2 Department of Chemistry, Ball State University, Muncie, Indiana, United States of America

Corresponding Author:

15 Melissa D. Evans $^{1}$

Email address: Melissa.evans96@outlook.com 
19 Abstract

20 Background. Chronic infection by Staphylococcus aureus drives pathogenesis in important

21 clinical settings, such as recurrent pulmonary infection in cystic fibrosis and relapsing infection

22 in osteomyelitis. Treatment options for intracellular S. aureus infection are limited. Rifampin, a

23 lipophilic antibiotic, readily penetrates host cell membranes, yet monotherapy is associated with

24 rapid antibiotic resistance and development of severe adverse events. Antibiotic cotreatment can

25 reduce this progression, yet efficacy diminishes as antibiotic resistance develops. ML141 and

26 simvastatin inhibit $S$. aureus invasion through host-directed rather than bactericidal mechanisms.

27 Objective. To determine whether cotreatment of ML141 or of simvastatin with rifampin would 28 enhance rifampin efficacy.

29 Methods. Assays to assess host cell invasion, host cell viability, host cell membrane

30 permeability, and bactericidal activity were performed using the human embryonic kidney

31 (HEK) 293-A cell line infected with $S$. aureus (29213) and treated with vehicle control,

32 simvastatin, ML141, rifampin, or cotreatment of simvastatin or ML141 with rifampin.

33 Results. We found cotreatment of ML141 with rifampin reduced intracellular infection nearly 85

$34 \%$ when compared to the no treatment control. This decrease more than doubled the average 40

$35 \%$ reduction in response to rifampin monotherapy. In contrast, cotreatment of simvastatin with

36 rifampin failed to improve rifampin efficacy. Also, in contrast to ML141, simvastatin increased

37 propidium iodide (PI) positive cells, from an average of $10 \%$ in control HEK 293-A cells to

38 nearly $20 \%$ in simvastatin-treated cells, indicating an increase in host cell membrane

39 permeability. The simvastatin-induced increase was reversed to control levels by cotreatment of 40 simvastatin with rifampin. 
41 Conclusion. Taken together, rifampin efficacy is increased through host-directed inhibition of $S$.

42 aureus invasion by ML141, while efficacy is not increased by simvastatin. Considerations

43 regarding novel therapeutic approaches may be dependent on underlying differences in

44 pharmacology.

45 Introduction

Staphylococcus aureus is an important cause of both acute [1] and chronic infections

47 [2,3]. Chronic infections contribute substantially to morbidity and mortality in certain settings,

48 most notably in progressive lung disease characteristic of cystic fibrosis (CF) [3] and in

49 deterioration of bone and joint tissue in osteomyelitis [2]. S. aureus is an initial pulmonary

50 isolate in pediatric patients with CF [4] and by adulthood the majority of CF patients remain

51 chronically infected [5,6]. Chronic $S$. aureus infection is an ongoing treatment challenge as

52 indicated by the 2018 Cystic Fibrosis Foundation Patient Registry reporting an increase in the

53 percentage of patients infected with S. aureus each year from 59\% in 2003 to $70 \%$ in 2018 [7].

54 S. aureus also is the most common cause of acute and chronic osteomyelitis in children and

55 adults $[2,8]$. Treatment of staphylococcal osteomyelitis is complicated further by increased

56 incidence of methicillin-resistant S. aureus (MRSA) infection. The predominance of S. aureus in

57 initiating and sustaining chronic infection may be attributable to the capacity to invade host cells,

58 to reemerge and invade adjoining cells and to undergo phenotypic differentiation within host

59 cells enabling persistence within the intracellular environment $[9,10,11]$.

$60 \quad$ S. aureus invades host cells by exploiting host endocytic mechanisms [12]. On the

61 bacterial surface, invasive $S$. aureus strains express fibronectin binding proteins (FnBPs) that

62 bind fibronectin, a host extracellular matrix protein. Fibronectin, as it binds to the host cell

63 receptor $\alpha 5 \beta 1$, triggers receptor-mediated endocytosis of the bacteria-fibronectin complex. 
64 During invasion, host cell actin stress fibers disassemble, potentially providing pulling forces

65 needed for engulfment $[13,14]$. CDC42, a member of the RHO GTPase family, regulates actin stress fiber dynamics and can function ahead of family members RAC and RHO in the mobilization of actin [15]. The apparent regulatory role and early CDC42 activation during $S$. aureus invasion [16] suggest host CDC42 plays a central role in this invasive mechanism.

Treatment options for intracellular S. aureus infection are limited as first-line antibiotics demonstrate limited membrane permeability [17]. Rifampin is a lipophilic antibiotic that demonstrates a propensity for intracellular uptake, enabling clearance of both extracellular and intracellular susceptible bacteria $[18,19]$. However, rifampin monotherapy is associated with the development of cross resistance to vancomycin and daptomycin [20], rapid rifampin resistance [21,22], and progression of severe adverse events [23,24]. To limit the development of resistance and adverse events, the current standard of care is cotreatment of rifampin with an antibiotic cocktail [25].

To circumvent antibiotic resistance, an emerging therapeutic approach is to target the host rather than bacterial cells $[13,26]$. For nearly two decades, researchers have examined statin drugs as potential host-directed therapeutics for infection, including invasive infection by $S$. aureus $[27,28,29,30,31]$. Our work had indicated therapeutic benefit may include limiting the spread of infection by reducing host cell invasion $[32,33,34]$. We identified an underlying mechanism where simvastatin reduces invasion of S. aureus into host cells by sequestering small-GTPases CDC42, RAC, and RHO in the cytosol [13]. In turn, this sequestration limits actin stress fiber disassembly and reduces fibronectin binding at $\alpha 5 \beta 1$ [35]. We went on to investigate whether targeted inhibition of host CDC42 would be sufficient to limit invasion. We discovered that ML141, a small molecule inhibitor with specificity for host CDC42 [36,37], decreased host cell 
87 invasion [26]. Similar to simvastatin, we found ML141 inhibition of invasion is associated with

88 diminished reordering of actin stress fibers and with decreased fibronectin binding at the host

89 cell membrane. Given simvastatin and ML141 reduce the number of bacteria that invade the host

90 cell and rifampin acts on both extracellular and intracellular bacterial populations, we sought to

91 determine in the current study whether cotreatment of these host-directed inhibitors with

92 rifampin would enhance clearance of intracellular infection. We examined the response to

93 cotreatment on intracellular infection, bactericidal activity, host cell membrane permeability, and

94 host cell viability.

95 Materials \& Methods

96 Human Embryonic Kidney (HEK) 293-A Cell Culture

97 HEK 293-A cells (Fisher Scientific) were cultured in Dulbecco's Modified Eagle's Medium

98 (VWR International, Radnor, PA; DMEM) supplemented with $10 \%$ fetal bovine serum (Atlanta

99 Biologicals, Flowery Branch, GA; FBS) and $1 \%$ L-glutamine (Fisher Scientific) and maintained 100 at $37^{\circ} \mathrm{C}, 5 \% \mathrm{CO}_{2}$, in $75 \mathrm{~cm}^{2}$ vented cap flasks (Fisher Scientific). HEK 293-A cell identity was

101 authenticated by short tandem repeat profiling performed by American Type Culture Collection

102 (ATCC, Manassas, VA).

103 Bacterial Cell Culture

104 Two days prior to each assay, Staphylococcus aureus (ATCC, \#29213) cultures were maintained

105 in $5 \mathrm{ml}$ tryptic soy broth (Sigma-Aldrich, St. Louis, MO) overnight $\left(37^{\circ} \mathrm{C}, 225 \mathrm{rpm}\right)$ then

106 subcultured one day prior to each assay.

107 Rifampin IC50

$108 S$. aureus cultures were harvested by centrifugation $\left(3 \mathrm{~min}, 37^{\circ} \mathrm{C}, 10,000 \mathrm{rpm}\right)$, resuspended to

$1095.4 \times 10^{8}$ colony forming units $(\mathrm{CFU}) / \mathrm{ml}$ in prewarmed $0.85 \%$ saline, and incubated with the 
110 vehicle control, $0.4 \%$ dimethyl sulfoxide (Fisher Scientific, Waltham, MA; DMSO), or with

111 increasing concentrations of rifampin (VWR International; structure provided in supplemental

112 file) $\left(1 \mathrm{hr}, 37^{\circ} \mathrm{C}, 5 \% \mathrm{CO}_{2}\right)$. Serial dilutions were incubated overnight on tryptic soy agar (Sigma-

113 Aldrich; TSA; $37^{\circ} \mathrm{C}$ ) and colony counts performed to determine $\mathrm{CFU} / \mathrm{ml}$. Of note, for all

114 experiments, $0.4 \%$ was the final DMSO solvent concentration ( $\mathrm{vol} / \mathrm{vol}$ ) for each treatment and

115 0.4\% DMSO served as the non-treatment, negative, vehicle control.

116 To determine the IC50 of rifampin for intracellular infection, $35 \mathrm{~mm}$ cell culture dishes (Fisher

117 Scientific) were precoated with Attachment Factor (Fisher Scientific) prior to plating $3 \times 10^{5}$

118 HEK 293-A cells $/ \mathrm{ml}$. HEK 293-A cells were inoculated with S. aureus at multiplicity of

119 infection (MOI) $2\left(6 \times 10^{5} \mathrm{CFU} / \mathrm{ml}\right)$ or at MOI $100\left(3 \times 10^{7} \mathrm{CFU}\right), 30 \mathrm{~min}$ or $1 \mathrm{hr}, 37^{\circ} \mathrm{C}, 5 \%$

$120 \mathrm{CO}_{2}$ ) in $10 \% \mathrm{FBS} /$ phosphate buffered saline (VWR International; PBS) followed by incubation

121 with increasing concentrations of rifampin $\left(1 \mathrm{hr}, 37^{\circ} \mathrm{C}, 5 \% \mathrm{CO}_{2}\right)$. To remove extracellular

122 bacteria, HEK 293-A cells were incubated with gentamicin (Sigma-Aldrich; $50 \mu \mathrm{g} / \mathrm{ml}$ ) and

123 lysostaphin (Sigma-Aldrich, $20 \mu \mathrm{g} / \mathrm{ml}$ ) in DMEM ( $45 \mathrm{~min}, 37^{\circ} \mathrm{C}, 5 \% \mathrm{CO}_{2}$ ) following three $1 \mathrm{X}$

124 PBS washes. Intracellular S. aureus were harvested using $1 \%$ saponin $\left(20 \mathrm{~min}, 37^{\circ} \mathrm{C}, 5 \% \mathrm{CO}_{2}\right)$

125 following three 1X PBS washes and serial dilutions of the supernatant were plated onto TSA,

126 incubated overnight at $37^{\circ} \mathrm{C}$ and $\mathrm{CFU} / \mathrm{ml}$ quantified by colony counts.

127 ML141 Pretreatment Assay

128 HEK 293-A cells were plated as described above. The following day, HEK 293-A cells were

129 pretreated with DMSO (0.4 \%) or with ML141 $\left(10 \mu \mathrm{M} ; 37^{\circ} \mathrm{C}, 5 \% \mathrm{CO}_{2}, 24 \mathrm{~h}\right.$; structure provided

130 in supplemental file). The next day, pretreated HEK 293-A cells were inoculated ( $3 \times 10^{7} \mathrm{CFU}, 1$

$\left.131 \mathrm{hr}, 37^{\circ} \mathrm{C}, 5 \% \mathrm{CO}_{2}\right)$ in $10 \% \mathrm{FBS} / \mathrm{PBS}$. Intracellular bacteria were isolated and quantified as

132 described above. 


\section{Cotreatment Assay}

134 HEK 293-A cells were plated as described above. Treatments were performed as outlined in

135 Table 1 at these concentrations: DMSO $(0.4 \%), \operatorname{ML} 141(10 \mu \mathrm{M})$, simvastatin $(1 \mu \mathrm{M}$; structure

136 provided in supplemental file $)$, rifampin $(0.01 \mathrm{mg} / \mathrm{L})$.

137 Following post-treatment, intracellular bacteria were isolated and quantified as described.

\section{Host Cell Viability Assay}

140 HEK 293-A cells were plated at $5 \times 10^{4}$ cells/ $0.5 \mathrm{ml}$ in 48 -well cell culture plates (VWR

141 International) precoated with Attachment Factor. To acquire uniform microplate readings, multi-

142 well culture plates were used. This change from the $35 \mathrm{~mm}$ plates used for the invasion assay

143 required a reduction in cell count. The following day, HEK 293-A cells were treated with DMSO

$144(0.4 \%)$, ML141 $(10 \mu \mathrm{M})$, rifampin $(0.01 \mathrm{mg} / \mathrm{L})$, or ML141 $(10 \mu \mathrm{M})$ with rifampin $(0.01 \mathrm{mg} / \mathrm{L}$;

$14524 \mathrm{hr}, 37^{\circ} \mathrm{C}, 5 \% \mathrm{CO}_{2}$ ). Cell viability was measured using CellTiter $96{ }^{\circledR}$ Aqueous One Solution

146 Reagent (Promega Corporation, Madison, WI). Absorbance was measured at $490 \mathrm{~nm}$ using a

147 BioRad iMark microplate reader.

148 Bactericidal Assay

149 S. aureus were harvested as described above and treated with DMSO (0.2 \%), ML141 (10 $\mu \mathrm{M})$,

150 rifampin $(0.002 \mathrm{mg} / \mathrm{L})$, or ML141 $(10 \mu \mathrm{M})$ with rifampin $\left(0.002 \mathrm{mg} / \mathrm{L} ; 1 \mathrm{hr}, 37^{\circ} \mathrm{C}, 5 \% \mathrm{CO}_{2}\right)$.

151 Bacteria were serially diluted, plated on TSA, incubated overnight at $37^{\circ} \mathrm{C}$ and $\mathrm{CFU} / \mathrm{ml}$

152 determined from colony counts.

153 Propidium Iodide Flow Cytometry Assay

154 HEK 293-A cells were plated and incubated with DMSO (0.4 \%), ML141 (10 $\mu \mathrm{M})$, or

155 simvastatin $(1 \mu \mathrm{M})$ as described in the cotreatment assay. The following day, HEK 293-A were 
156 treated with DMSO (0.4 \%), ML141 (10 $\mu \mathrm{M})$, simvastatin $(1 \mu \mathrm{M})$, rifampin $(0.01 \mathrm{mg} / \mathrm{L}), \mathrm{ML} 141$

$157(10 \mu \mathrm{M})$ with rifampin $(0.01 \mathrm{mg} / \mathrm{L})$, or simvastatin $(1 \mu \mathrm{M})$ with rifampin $\left(0.01 \mathrm{mg} / \mathrm{L} ; 1 \mathrm{hr}, 37^{\circ} \mathrm{C}\right.$,

$1585 \% \mathrm{CO}_{2}$ ). Immediately prior to performing the assay, HEK 293-A cells serving as the positive

159 control were incubated with 70\% ethanol (1 min). HEK 293-A cells were harvested by scrapping

160 with cell lifters and washed in FACS buffer. Propidium iodide (Sigma Aldrich) was added to

161 each sample immediately prior to measurement. Percentage of propidium iodide positive HEK

162 293-A cells was determined using a MACSQuant Analyzer 10 flow cytometer (Miltenyi Biotech

163 Inc., Auburn, CA.).

164 Statistical Analysis

165 All data were analyzed using Prism software (GraphPad Software Inc., San Diego, CA).

166 Rifampin IC50 was determined by nonlinear regression analysis. Means between groups were

167 compared by one-way ANOVA followed by Newman-Keuls or Holm-Sidak's post-hoc analysis.

168 The threshold for statistical significance was $P<0.05$.

169 Results

170 Cotreatment of rifampin with ML141 reduces intracellular S. aureus infection more than

171 rifampin alone

172 We first determined the half maximal inhibitory concentration (IC50) of rifampin in a

173 model cell line, HEK 293-A. The rifampin IC50 was 0.004 mg/L when HEK 293-A cells were

174 incubated with bacteria at MOI 2 and the IC50 increased to $0.01 \mathrm{mg} / \mathrm{L}$ when the MOI was

175 increased to 100 (Fig. 1). Thus, a higher concentration of antibiotic was needed to clear a larger

176 intracellular bacterial population. All subsequent experiments were performed at MOI 100 to

177 ensure there were sufficient numbers of colonies in the cotreatment group for statistical analysis. 
179 pretreatment of HEK 293-A cells with $10 \mu \mathrm{M}$ ML141 reduced the number of intracellular

180 bacteria by an average of $40 \%$ when compared to pretreatment with the negative, vehicle control 181 DMSO (Fig. 2, Panel A, $P=0.0169$ ). Therefore, this concentration of ML141 served as the 182 positive control for all subsequent experiments. Also consistent with our work and that of others $183[38,39]$, the experimental design used throughout this study is one of pretreatment. Pretreatment 184 is not used as a model for prophylactic clinical applications, but rather, as a model for limiting 185 the spread of infection post-onset and diagnosis, given the evidence that invasive $S$. aureus 186 strains successfully exit infected host cells to initiate new infection $[11,40,41]$. We found 187 cotreatment of $10 \mu \mathrm{M}$ ML141 with rifampin at the IC50 decreased the number of intracellular 188 bacteria more than ML141 or rifampin alone (Fig. 2, Panel B, $P<0.0001$ ). Thus, cotreatment of 189 ML141 with rifampin appeared to enhance bacterial clearance.

190

Underlying mechanisms for enhanced clearance are not associated with an appreciable loss 192 in host cell viability or loss of host cell membrane integrity We next assessed whether the reduction in the number of intracellular bacteria was due to decreased numbers of viable host cells rather than to enhanced bacterial clearance. HEK 293-A cells were incubated with the DMSO control, ML141 alone, rifampin alone, or ML141 combined with rifampin for the same length of time as had been used for the invasion assay. HEK 293-A

197 metabolic activity was assayed by measuring the conversion of a tetrazolium compound to 198 formazan, a colored product detectable by absorbance at $490 \mathrm{~nm}$. Compared to the DMSO 199 control group, no decrease in absorbance was detected in any treatment group, indicating 
200 treatment did not diminish metabolic activity, an indicator of sustained cell viability (Fig. 3, 201 Panel A).

202

We went on to assess whether clearance of intracellular infection might be attributable to

203

204

205

206

207

208

209

210

211

212 Underlying mechanisms for enhanced clearance by the co-treatment are not associated 213

214

215

216

217

218

219

220

221

increased host membrane permeability, allowing greater penetrance of antibiotic into the intracellular compartment. HEK 293-A cells were incubated with the vehicle control DMSO or with ML141, rifampin, or ML141 combined with rifampin for the same duration as had been used for the invasion assay. Host cell membrane permeability was assessed using propidium iodide uptake. The percentage of propidium iodide positive HEK 293-A cells, an indication of membrane permeability, remained at DMSO control levels in response to each treatment, indicating HEK 293-A host cell membrane integrity is maintained following incubation with all treatments (Fig. 3, Panels B and C).

\section{with appreciable ML141 bactericidal activity or with enhanced rifampin bactericidal} activity

Although ML141 has been assessed repeatedly for bactericidal activity and no such activity has been detected toward multiple S. aureus or Streptococcus pyogenes strains [26,35], we saw it as important to verify this under the experimental conditions of the rifampin studies. We inoculated HEK 293-A media containing the DMSO control or $10 \mu \mathrm{M}$ ML141 for the same length of time used in the invasion assay. We found that the number of viable bacteria following ML141 treatment was similar to the control treated group, indicating ML141 exhibited no bactericidal activity under the conditions used for the invasion assay (Fig. 4, Panel B). 
223

224 225 226 227 228

bactericidal activity, we first needed to determine the IC50 of rifampin on $S$. aureus ATCC 29213 growth in axenic (host cell-free) conditions. This was necessary because the rifampin IC50 for intracellular bacteria $(0.01 \mathrm{mg} / \mathrm{L}$, reported above) was expected to exceed the IC50 needed under axenic conditions. Consistent with this expectation, the IC50 of rifampin in the absence of host cells was $0.002 \mathrm{mg} / \mathrm{L}$ (Fig. 4, Panel A). We then found the number of viable bacteria following cotreatment of $10 \mu \mathrm{M}$ ML141 with rifampin at the IC50 for axenic conditions was similar to the number of bacteria recovered following rifampin alone, indicating no detectable enhancement of rifampin bactericidal activity by ML141 at the concentrations used (Fig. 4, Panel C, $P=0.0005)$.

\section{Cotreatment of simvastatin with rifampin fails to improve rifampin efficacy}

We went on to explore the hypothesis that cotreatment of rifampin with the host-directed therapeutic simvastatin might achieve similar enhancement in the clearance of intracellular infection. The hypothesis was based on our earlier findings that $1.0 \mu \mathrm{M}$ simvastatin decreases intracellular infection in part by sequestering host GTPases, including CDC42 [13], the hostdirected target of ML141 [36,37]. Moreover, both ML141 and simvastatin disrupt actin dynamics necessary for host cell invasion by $S$. aureus and by Streptococcus pyogenes [26,35]. Contrary to the hypothesis, we found no enhancement of bacterial clearance was achieved by cotreatment of rifampin with simvastatin (Fig. 5, Panel A, $P=0.0124$ ).

\section{Differential effect of simvastatin on HEK 293-A cell membrane permeability is reversed by} cotreatment 
earlier work, we [35] and others [38] had found that simvastatin can induce host cell membrane

247 permeability in specific cell types. We examined the effect of simvastatin on HEK 293-A cell

248 membrane permeability and the effect of rifampin cotreatment. We found in contrast to ML141

249 (Fig. 3, Panel B), simvastatin treatment increased HEK 293-A cell permeability (Fig. 5, Panel B, $250 P=0.0042)$. We also found the increase in membrane permeability in response to simvastatin 251 was reversed by cotreatment with rifampin (Fig. 5, Panels B and C).

\section{Discussion}

In this study, we report cotreatment of ML141 with rifampin decreases intracellular infection more than rifampin monotherapy (Fig. 2). Improved clearance is achieved through

mechanisms that sustain host cell viability and host membrane integrity (Fig. 3) in the absence of detectable improvement of rifampin bactericidal activity (Fig. 4).

In contrast, cotreatment of cholesterol-lowering simvastatin with rifampin yielded no detectable improvement in bacterial clearance (Fig. 5). To explore the differential response between ML141 and simvastatin, we compared effects on host membrane permeability. We found that in contrast to ML141, simvastatin increases membrane permeability. This finding is consistent with earlier reports by our group and others that simvastatin induces membrane permeability in specific cell types [35,38]. Statins exert pleiotropic effects through inhibition of integrity through decreased synthesis of the intermediate mevalonate $[42,43]$. Yet, loss of 
267 examination of simvastatin across multiple cell types, timepoints and dosages may have yielded 268 a response similar to ML141.

269 We found the increase in membrane permeability by simvastatin was reversed by

270 rifampin cotreatment. The return to baseline in response to cotreatment may be due to host-

271 directed effects of rifampin. Rifampin not only acts through inhibition of bacterial RNA

272 polymerase but also through host-directed responses, including induction of members of a

273 subclass of the mammalian ATP-binding cassette family, the multidrug resistance protein (MRP)

274 transporters [45]. Statin drugs can undergo efflux from the cell via these MRP transporters [46].

275 Our observation that membrane permeability returned to baseline in the cotreatment group would

276 be consistent with statin efflux driven by rifampin induction of these transporters. Similarly, the

277 failure of cotreatment to improve bacterial clearance also would be consistent with rifampin-

278 driven statin efflux. However, such conclusions await further experimental evidence.

279 Differences in the mode-of-action of simvastatin and ML141 also may contribute to the 280 differences observed in response to cotreatment. Simvastatin inhibits 3-hydroxy-3-

281 methylglutaryl coenzyme A (HMG-CoA) reductase, the rate limiting enzyme in the cholesterol

282 biosynthesis pathway [28]. Inhibition of HMG-CoA reductase decreases synthesis of cholesterol, 283 as well as isoprenoid intermediates synthesized in the pathway [47]. Isoprenoid intermediates 284 can serve as membrane anchors for CaaX domain containing proteins, including CDC42 [47], 285 and decreased synthesis of isoprenoid intermediates limits CDC42 membrane localization [13]. 286 Although simvastatin inhibits membrane localization of CDC42, activation of CDC42 by GTP 287 binding within the activation site is sustained [48]. This is in contrast to ML141, an allosteric 288 inhibitor with specificity for human CDC42 [36,37]. ML141 dissociates GTP within the 289 activation site of $\mathrm{CDC} 42$, decreasing $\mathrm{CDC} 42$ activation [36]. Another distinction between 
290 simvastatin and ML141 is that simvastatin inhibits membrane localization of additional CaaX-

291 domain containing proteins, including RAC and RHO [49]. Thus, simvastatin affects multiple

292 small GTPases, whereas ML141 has demonstrated specificity for CDC42, with no inhibitory

293 activity detected toward RAC or RHO [36]. These distinctions in the mode-of-action and

294 underlying pharmacology of simvastatin and ML141 could contribute to the observed differences

295 in response to cotreatment.

296 Our findings indicate not only the promise of host-directed therapeutic approaches such

297 as ML141, but also potential limitations of combinatorial therapies, such as the use of

298 simvastatin with rifampin. Targeting host cell invasion may indeed have therapeutic benefit

299 when done in combination with antibiotics, but careful examination of underlying mechanisms

300 continues to be warranted.

301 Conclusions

302 We sought to determine whether cotreatment of the host-directed therapeutics ML141 or

303 simvastatin with the lipophilic antibiotic rifampin enhances clearance of intracellular S. aureus.

304 We found cotreatment of ML141 with rifampin enhanced rifampin efficacy, while cotreatment of

305 simvastatin with rifampin failed to improve rifampin efficacy. Simvastatin monotherapy

306 increased host cell permeability, while ML141 monotherapy did not. Increases in host cell

307 permeability in response to simvastatin were reversed by rifampin. Differences in the underlying

308 pharmacology of simvastatin and ML141 may contribute to differences observed in response to

309 cotreatment and should be considered when assessing the efficacy of use with antibiotics.

\section{References}

311

312

313

314

315

316
[1] S.Y. Tong, J.S. Davis, E. Eichenberger, T.L. Holland, V.G. Fowler, Jr., Staphylococcus aureus infections: epidemiology, pathophysiology, clinical manifestations, and management, Clin Microbiol Rev 28 (2015) 603-661.

[2] N. Kavanagh, E.J. Ryan, A. Widaa, G. Sexton, J. Fennell, S. O'Rourke, K.C. Cahill, C.J. Kearney, F.J. O'Brien, S.W. Kerrigan, Staphylococcal Osteomyelitis: Disease 
Progression, Treatment Challenges, and Future Directions, Clin Microbiol Rev 31 (2018).

[3] C.H. Goss, M.S. Muhlebach, Review: Staphylococcus aureus and MRSA in cystic fibrosis, J Cyst Fibros 10 (2011) 298-306.

[4] D.S. Armstrong, K. Grimwood, J.B. Carlin, R. Carzino, J.P. Gutierrez, J. Hull, A. Olinsky, E.M. Phelan, C.F. Robertson, P.D. Phelan, Lower airway inflammation in infants and young children with cystic fibrosis, Am J Respir Crit Care Med 156 (1997) 1197-1204.

[5] C. Branger, C. Gardye, N. Lambert-Zechovsky, Persistence of Staphylococcus aureus strains among cystic fibrosis patients over extended periods of time, J Med Microbiol 45 (1996) 294-301.

[6] M. Schwerdt, C. Neumann, B. Schwartbeck, S. Kampmeier, S. Herzog, D. Gorlich, A. Dubbers, J. Grosse-Onnebrink, C. Kessler, P. Kuster, H. Schultingkemper, J. Treffon, G. Peters, B.C. Kahl, Staphylococcus aureus in the airways of cystic fibrosis patients - A retrospective long-term study, Int J Med Microbiol 308 (2018) 631-639.

[7] C.F. Foundation, 2018 Patient Registry Annual Data Report, 2019.

[8] J. Hatzenbuehler, T.J. Pulling, Diagnosis and management of osteomyelitis, Am Fam Physician 84 (2011) 1027-1033.

[9] B. Loffler, L. Tuchscherr, S. Niemann, G. Peters, Staphylococcus aureus persistence in nonprofessional phagocytes, Int J Med Microbiol 304 (2014) 170-176.

[10] R.A. Proctor, C. von Eiff, B.C. Kahl, K. Becker, P. McNamara, M. Herrmann, G. Peters, Small colony variants: a pathogenic form of bacteria that facilitates persistent and recurrent infections, Nat Rev Microbiol 4 (2006) 295-305.

[11] L. Tuchscherr, E. Medina, M. Hussain, W. Volker, V. Heitmann, S. Niemann, D. Holzinger, J. Roth, R.A. Proctor, K. Becker, G. Peters, B. Loffler, Staphylococcus aureus phenotype switching: an effective bacterial strategy to escape host immune response and establish a chronic infection, EMBO Mol Med 3 (2011) 129-141.

[12] T.J. Foster, J.A. Geoghegan, V.K. Ganesh, M. Hook, Adhesion, invasion and evasion: the many functions of the surface proteins of Staphylococcus aureus, Nat Rev Microbiol 12 (2014) 49-62.

[13] M.P. Horn, S.M. Knecht, F.L. Rushing, J. Birdsong, C.P. Siddall, C.M. Johnson, T.N. Abraham, A. Brown, C.B. Volk, K. Gammon, D.L. Bishop, J.L. McKillip, S.A. McDowell, Simvastatin inhibits Staphylococcus aureus host cell invasion through modulation of isoprenoid intermediates, J Pharmacol Exp Ther 326 (2008) 135-143.

[14] F. Agerer, S. Lux, A. Michel, M. Rohde, K. Ohlsen, C.R. Hauck, Cellular invasion by Staphylococcus aureus reveals a functional link between focal adhesion kinase and cortactin in integrin-mediated internalisation, J Cell Sci 118 (2005) 2189-2200.

[15] C.D. Nobes, A. Hall, Rho, rac, and cdc42 GTPases regulate the assembly of multimolecular focal complexes associated with actin stress fibers, lamellipodia, and filopodia, Cell 81 (1995) 53-62.

[16] L. Arbibe, J.P. Mira, N. Teusch, L. Kline, M. Guha, N. Mackman, P.J. Godowski, R.J. Ulevitch, U.G. Knaus, Toll-like receptor 2-mediated NF-kappa B activation requires a Rac1-dependent pathway, Nat Immunol 1 (2000) 533-540.

[17] R.O. Darouiche, R.J. Hamill, Antibiotic penetration of and bactericidal activity within endothelial cells, Antimicrob Agents Chemother 38 (1994) 1059-1064.

[18] P.H. Hoger, K. Vosbeck, R. Seger, W.H. Hitzig, Uptake, intracellular activity, and influence of rifampin on normal function of polymorphonuclear leukocytes, Antimicrob Agents Chemother 28 (1985) 667-674.

[19] G.L. Mandell, T.K. Vest, Killing of intraleukocytic Staphylococcus aureus by rifampin: invitro and in-vivo studies, J Infect Dis 125 (1972) 486-490.

[20] R. Guerillot, A. Goncalves da Silva, I. Monk, S. Giulieri, T. Tomita, E. Alison, J. Porter, S. Pidot, W. Gao, A.Y. Peleg, T. Seemann, T.P. Stinear, B.P. Howden, Convergent 
368

369

370

371

372

373

374

375

376

377

378

379

380

381

382

383

384

385

386

387

388

389

390

391

392

393

394

395

396

397

398

399

400

401

402

403

404

405

406

407

408

409

410

411

412

413

414

415

416

417

418

Evolution Driven by Rifampin Exacerbates the Global Burden of Drug-Resistant Staphylococcus aureus, mSphere 3 (2018).

[21] W. Zhou, W. Shan, X. Ma, W. Chang, X. Zhou, H. Lu, Y. Dai, Molecular characterization of rifampicin-resistant Staphylococcus aureus isolates in a Chinese teaching hospital from Anhui, China, BMC Microbiol 12 (2012) 240.

[22] D. Bongiorno, G. Mongelli, S. Stefani, F. Campanile, Burden of Rifampicin- and MethicillinResistant Staphylococcus aureus in Italy, Microb Drug Resist 24 (2018) 732-738.

[23] G. Poole, P. Stradling, S. Worlledge, Potentially serious side effects of high-dose twiceweekly rifampicin, Br Med J 3 (1971) 343-347.

[24] J. Grosset, S. Leventis, Adverse effects of rifampin, Rev Infect Dis 5 Suppl 3 (1983) S440450.

[25] G.N. Forrest, K. Tamura, Rifampin combination therapy for nonmycobacterial infections, Clin Microbiol Rev 23 (2010) 14-34.

[26] D. Cordero, C.R. Fullenkamp, R.R. Pelly, K.M. Reed, L.M. Caffo, A.N. Zahrt, M. Newman, S. Komanapalli, E.M. Niemeier, D.L. Bishop, H.A. Bruns, M.K. Haynes, L.A. Sklar, R.E. Sammelson, S.A. McDowell, Small Molecule Inhibitors Limit Endothelial Cell Invasion by Staphylococcus aureus, Curr Pharm Biotechnol 15 (2014) 727-737.

[27] A. Zumla, M. Rao, R.S. Wallis, S.H. Kaufmann, R. Rustomjee, P. Mwaba, C. Vilaplana, D. Yeboah-Manu, J. Chakaya, G. Ippolito, E. Azhar, M. Hoelscher, M. Maeurer, c. HostDirected Therapies Network, Host-directed therapies for infectious diseases: current status, recent progress, and future prospects, Lancet Infect Dis 16 (2016) e47-63.

[28] E. Hennessy, C. Adams, F.J. Reen, F. O'Gara, Is There Potential for Repurposing Statins as Novel Antimicrobials?, Antimicrob Agents Chemother 60 (2016) 5111-5121.

[29] A.R. Caffrey, T.T. Timbrook, E. Noh, G. Sakoulas, S.M. Opal, V. Nizet, K.L. LaPlante, Evidence To Support Continuation of Statin Therapy in Patients with Staphylococcus aureus Bacteremia, Antimicrob Agents Chemother 61 (2017).

[30] S.P. Parihar, R. Guler, F. Brombacher, Statins: a viable candidate for host-directed therapy against infectious diseases, Nat Rev Immunol 19 (2019) 104-117.

[31] S.H.E. Kaufmann, A. Dorhoi, R.S. Hotchkiss, R. Bartenschlager, Host-directed therapies for bacterial and viral infections, Nat Rev Drug Discov 17 (2018) 35-56.

[32] E.M. Burns, L.K. Smelser, J.E. Then, T.E. Stankiewicz, M. Kushdilian, S.A. McDowell, H.A. Bruns, Short term statin treatment improves survival and differentially regulates macrophage-mediated responses to Staphylococcus aureus, Curr Pharm Biotechnol 14 (2013) 233-241.

[33] L.K. Smelser, C. Walker, E.M. Burns, M. Curry, N. Black, J.A. Metzler, S.A. McDowell, H.A. Bruns, Short Term, Low Dose Simvastatin Pretreatment Alters Memory Immune Function Following Secondary Staphylococcus aureus Infection, Curr Pharm Biotechnol 17 (2016) 886-893.

[34] S.A. McDowell, Y. Ma, R. Kusano, H.T. Akinbi, Simvastatin is protective during Staphylococcus aureus pneumonia, Curr Pharm Biotechnol 12 (2011) 1455-1462.

[35] L. Caffo, B.L. Sneed, C. Burcham, K. Reed, N.C. Hahn, S. Bell, O. Downham, M.D. Evans, C.R. Fullenkamp, T.K. Drinnon, D. Bishop, H.A. Bruns, J.L. McKillip, R.E. Sammelson, S.A. McDowell, Simvastatin and ML141 Decrease Intracellular Streptococcus pyogenes Infection, Curr Pharm Biotechnol 20 (2019) 733-744.

[36] L. Hong, S.R. Kenney, G.K. Phillips, D. Simpson, C.E. Schroeder, J. Noth, E. Romero, S. Swanson, A. Waller, J.J. Strouse, M. Carter, A. Chigaev, O. Ursu, T. Oprea, B. Hjelle, J.E. Golden, J. Aube, L.G. Hudson, T. Buranda, L.A. Sklar, A. Wandinger-Ness, Characterization of a Cdc42 protein inhibitor and its use as a molecular probe, $\mathrm{J}$ Biol Chem 288 (2013) 8531-8543.

[37] Z. Surviladze, A. Waller, J.J. Strouse, C. Bologa, O. Ursu, V. Salas, J.F. Parkinson, G.K. Phillips, E. Romero, A. Wandinger-Ness, L.A. Sklar, C. Schroeder, D. Simpson, J. Noth,

Peer) reviewing PDF | (2020:06:50566:2:0:NEW 11 Oct 2020) 
419

420

421

422

423

424

425

426

427

428

429

430

431

432

433

434

435

436

437

438

439

440

441

442

443

444

445

446

447

448

449

450

451

452

453

454

455

456

457

458

459

460

461

J. Wang, J. Golden, J. Aube, A Potent and Selective Inhibitor of Cdc42 GTPase, Probe Reports from the NIH Molecular Libraries Program, Bethesda (MD), 2010.

[38] O.A. Chow, M. von Kockritz-Blickwede, A.T. Bright, M.E. Hensler, A.S. Zinkernagel, A.L. Cogen, R.L. Gallo, M. Monestier, Y. Wang, C.K. Glass, V. Nizet, Statins enhance formation of phagocyte extracellular traps, Cell Host Microbe 8 (2010) 445-454.

[39] M.W. Merx, E.A. Liehn, U. Janssens, R. Lutticken, J. Schrader, P. Hanrath, C. Weber, HMG-CoA reductase inhibitor simvastatin profoundly improves survival in a murine model of sepsis, Circulation 109 (2004) 2560-2565.

[40] H.D. Gresham, J.H. Lowrance, T.E. Caver, B.S. Wilson, A.L. Cheung, F.P. Lindberg, Survival of Staphylococcus aureus inside neutrophils contributes to infection, J Immunol 164 (2000) 3713-3722.

[41] J. Jubrail, P. Morris, M.A. Bewley, S. Stoneham, S.A. Johnston, S.J. Foster, A.A. Peden, R.C. Read, H.M. Marriott, D.H. Dockrell, Inability to sustain intraphagolysosomal killing of Staphylococcus aureus predisposes to bacterial persistence in macrophages, Cell Microbiol 18 (2016) 80-96.

[42] A. Chimento, I. Casaburi, P. Avena, F. Trotta, A. De Luca, V. Rago, V. Pezzi, R. Sirianni, Cholesterol and Its Metabolites in Tumor Growth: Therapeutic Potential of Statins in Cancer Treatment, Front Endocrinol (Lausanne) 9 (2018) 807.

[43] M. Rauthan, M. Pilon, The mevalonate pathway in C. elegans, Lipids Health Dis 10 (2011) 243.

[44] A.C. Rodrigues, R. Curi, F.D. Genvigir, M.H. Hirata, R.D. Hirata, The expression of efflux and uptake transporters are regulated by statins in Caco-2 and HepG2 cells, Acta Pharmacol Sin 30 (2009) 956-964.

[45] M.F. Fromm, H.M. Kauffmann, P. Fritz, O. Burk, H.K. Kroemer, R.W. Warzok, M. Eichelbaum, W. Siegmund, D. Schrenk, The effect of rifampin treatment on intestinal expression of human MRP transporters, Am J Pathol 157 (2000) 1575-1580.

[46] M.J. Knauer, B.L. Urquhart, H.E. Meyer zu Schwabedissen, U.I. Schwarz, C.J. Lemke, B.F. Leake, R.B. Kim, R.G. Tirona, Human skeletal muscle drug transporters determine local exposure and toxicity of statins, Circ Res 106 (2010) 297-306.

[47] J. Greenwood, L. Steinman, S.S. Zamvil, Statin therapy and autoimmune disease: from protein prenylation to immunomodulation, Nat Rev Immunol 6 (2006) 358-370.

[48] T.E. Stankiewicz, K.L. Haaning, J.M. Owens, A.S. Jordan, K. Gammon, H.A. Bruns, S.A. McDowell, GTPase activating protein function of p85 facilitates uptake and recycling of the beta1 integrin, Biochem Biophys Res Commun 391 (2010) 443-448.

[49] J.K. Liao, U. Laufs, Pleiotropic effects of statins, Annu Rev Pharmacol Toxicol 45 (2005) 89-118.

\section{Figure Legends}

Figure $1 A$ higher concentration of rifampin is required when there is an increase in the

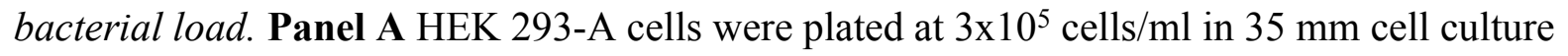

dishes. Two days later, cells were infected at a multiplicity of infection (MOI) of $2\left(6 \times 10^{5}\right.$

Staphylococcus aureus colony forming units; $\mathrm{CFU} ; 30 \mathrm{~min}, 37^{\circ} \mathrm{C}, 5 \% \mathrm{CO}_{2}$ ) then treated with

dimethyl sulfoxide (DMSO), or $0.001,0.003,0.01$, or $0.03 \mathrm{mg} / \mathrm{L}$ rifampin $\left(1 \mathrm{hr}, 37^{\circ} \mathrm{C}, 5 \% \mathrm{CO}_{2}\right)$.

PeerJ reviewing PDF | (2020:06:50566:2:0:NEW 11 Oct 2020) 
462 HEK 293-A cells were treated with gentamicin $(50 \mu \mathrm{g} / \mathrm{ml})$ and lysostaphin $(20 \mu \mathrm{g} / \mathrm{ml} ; 45 \mathrm{~min}$, $46337^{\circ} \mathrm{C}, 5 \% \mathrm{CO}_{2}$ ) to remove extracellular bacteria and intracellular bacteria were harvested using $4641 \%$ saponin $\left(20 \mathrm{~min}, 37^{\circ} \mathrm{C}, 5 \% \mathrm{CO}_{2}\right)$. Serial dilutions were plated on tryptic soy agar $(24 \mathrm{hr}$, $46537^{\circ} \mathrm{C}$ ) and colony counts were performed. Data are pooled from two independent experiments 466 and are represented as $\mathrm{CFU} / \mathrm{ml} \pm \mathrm{SEM}(\mathrm{n}=4-8 /$ treatment$)$. Panel B HEK 293-A cells were 467 plated as described above and infected at MOI of $100\left(3 \times 10^{7} \mathrm{CFU} ; 1 \mathrm{hr}, 37^{\circ} \mathrm{C}, 5 \% \mathrm{CO}_{2}\right)$. $\mathrm{HEK}$ 468 293-A cells were treated with DMSO, or $0.003,0.01,0.03$, or $0.1 \mathrm{mg} / \mathrm{L}$ rifampin $\left(1 \mathrm{hr}, 37^{\circ} \mathrm{C}, 5\right.$ $469 \% \mathrm{CO}_{2}$ ). Extracellular bacteria were killed, intracellular bacteria harvested, and $\mathrm{CFU} / \mathrm{ml}$ 470 determined as described above. Data are represented as CFU/ml \pm SEM $(n=4 /$ treatment $)$.

471

472 Figure 2 Pretreatment with ML141 and cotreatment of ML141 with rifampin reduces 473 intracellular Staphylococcus aureus infection. Panel A HEK 293-A cells were plated at 3 x $10^{5}$ 474 cells $/ \mathrm{ml}$ in $35 \mathrm{~mm}$ cell culture dishes. The following day, cells were treated with dimethyl 475 sulfoxide (DMSO) or ML141 $\left(10 \mu \mathrm{M} ; 24 \mathrm{hr}, 37^{\circ} \mathrm{C}, 5 \% \mathrm{CO}_{2}\right)$. HEK 293-A cells were infected at 476 a multiplicity of infection (MOI) of $2\left(30 \mathrm{~min}, 37^{\circ} \mathrm{C}, 5 \% \mathrm{CO}_{2}\right)$ then were treated with 477 gentamicin $(50 \mu \mathrm{g} / \mathrm{ml})$ and lysostaphin $\left(20 \mu \mathrm{g} / \mathrm{ml} ; 45 \mathrm{~min}, 37^{\circ} \mathrm{C}, 5 \% \mathrm{CO}_{2}\right)$ to remove 478 extracellular bacteria. Intracellular bacteria were harvested using $1 \%$ saponin $\left(20 \mathrm{~min}, 37^{\circ} \mathrm{C}, 5\right.$ $\left.479 \% \mathrm{CO}_{2}\right)$ and serial dilutions were plated on tryptic soy agar $\left(24 \mathrm{hr}, 37^{\circ} \mathrm{C}\right)$. Intracellular bacteria 480 were quantified by colony counts. Data are represented as colony forming units (CFU)/ml \pm 481 SEM (* less than DMSO, $P<0.05$ by Student's $t$-test, $\mathrm{n}=4$ /treatment). Panel B HEK 293-A 482 cells were plated and pretreated with ML141 or DMSO as described above. HEK 293-A cells 483 were infected at MOI of 100 by incubating with $3 \times 10^{7}$ S. aureus CFU then were treated with 484 DMSO, ML141 $(10 \mu \mathrm{M})$, rifampin $(0.01 \mathrm{mg} / \mathrm{L})$, or cotreatment of ML141 $(10 \mu \mathrm{M})$ with rifampin 
$485\left(0.01 \mathrm{mg} / \mathrm{L} ; 1 \mathrm{hr}, 37^{\circ} \mathrm{C}, 5 \% \mathrm{CO} 2\right)$. Extracellular bacteria were killed, and intracellular bacteria 486 were harvested and plated as described above. Data are represented by CFU/ml $\pm \mathrm{SEM}$ (* less 487 than DMSO and ML141, ** less than DMSO, ML141, or rifampin, $P<0.05$ by one-way 488 ANOVA followed by Holm-Sidak's post-hoc analysis, $n=4 /$ treatment). Data are representative 489 of three replicate experiments.

490

491 Figure 3 HEK 293-A cell viability and membrane integrity are maintained following cotreatment 492 of ML141 with rifampin. Panel A HEK 293-A cells were plated at 5 x $10^{4}$ cells/well in a 48-well 493 plate. The following day, cells were treated with dimethyl sulfoxide (DMSO), ML141 (10 $\mu$ M), 494 rifampin $(0.01 \mathrm{mg} / \mathrm{L})$, or cotreatment of ML141 $(10 \mu \mathrm{M})$ and rifampin $\left(0.01 \mathrm{mg} / \mathrm{L} ; 24 \mathrm{hr}, 37^{\circ} \mathrm{C}\right.$, $\left.4955 \% \mathrm{CO}_{2}\right)$. Host cell viability was quantified following incubation with the CellTiter 96® 496 AQueous One Solution Reagent $\left(1 \mathrm{hr}, 37^{\circ} \mathrm{C}, 5 \% \mathrm{CO}_{2}\right)$. Absorbance was measured at $490 \mathrm{~nm}$ 497 using a BioRad iMark Microplate Reader. Data are represented as absorbance $\pm \operatorname{SEM}(P>0.05$ 498 by one-way ANOVA followed by Holm-Sidak's post-hoc analysis, $n=4 /$ treatment). Panel B 499 HEK 293-A cells were plated at $3 \times 10^{5}$ cells $/ \mathrm{ml}$ in $35 \mathrm{~mm}$ cell culture dishes. HEK 293-A cells 500 were treated with dimethyl sulfoxide (DMSO) or ML141 $\left(10 \mu \mathrm{M} ; 24 \mathrm{hr}, 37^{\circ} \mathrm{C}, 5 \% \mathrm{CO}_{2}\right)$. The 501 next day, cells were treated with DMSO, ML141 $(10 \mu \mathrm{M})$, rifampin $(0.01 \mathrm{mg} / \mathrm{L})$, or cotreatment 502 of ML141 $(10 \mu \mathrm{M})$ and rifampin $\left(0.01 \mathrm{mg} / \mathrm{L} ; 1 \mathrm{hr}, 37^{\circ} \mathrm{C}, 5 \% \mathrm{CO}_{2}\right)$. HEK 293-A cells were 503 harvested and resuspended in FACS buffer, then stained with propidium iodide (PI). Samples 504 were analyzed using a MACSQuant Analyzer 10 flow cytometer. Data are represented as percent $505 \mathrm{PI}^{+}$cells \pm SEM $(P>0.05$ by one-way ANOVA followed by Holm-Sidak's post-hoc analysis, $\mathrm{n}$ $506=3 /$ treatment). Data are pooled from two independent experiments. Panel C Representative 507 histogram from PI assay indicates similar levels of PI uptake by HEK 293-A cells treated with 
508 DMSO (green), ML141 (black), rifampin (purple), or rifampin with ML141 as cotreatment (red).

509 The overlay of histograms reveals nearly overlapping peaks for each treatment.

510

511

512 Figure 4 Rifampin bactericidal activity is not enhanced by ML141. Panel A Rifampin IC50

513 under axenic conditions is $0.002 \mathrm{mg} / \mathrm{L} .3 \times 10^{7}$ Staphylococcus aureus colony forming units

514 (CFU) were incubated with increasing concentrations of rifampin or dimethyl sulfoxide (DMSO;

$\left.5151 \mathrm{hr}, 37^{\circ} \mathrm{C}, 5 \% \mathrm{CO}_{2}\right)$. Serial dilutions were plated on tryptic soy agar $\left(24 \mathrm{hr}, 37^{\circ} \mathrm{C}\right)$ and colony

516 counts were performed. Data are represented as CFU/ml $\pm \operatorname{SEM}(n=3 /$ treatment $)$. Panel B

517 ML141 bactericidal activity not detected at concentrations used. Following treatment of $3 \times 10^{7}$

518 Staphylococcus aureus colony forming units (CFU) with dimethyl sulfoxide (DMSO) or ML141

$519\left(10 \mu \mathrm{M} ; 1 \mathrm{hr}, 37^{\circ} \mathrm{C}, 5 \% \mathrm{CO}_{2}\right)$, serial dilutions were plated onto tryptic soy agar $\left(24 \mathrm{hr}, 37^{\circ} \mathrm{C}\right)$

520 and colony counts were performed. Data are represented by CFU/ml $\pm \mathrm{SEM}(P>0.05$ by one-

521 way ANOVA followed by Holm-Sidak's post-hoc analysis, $\mathrm{n}=3$ /treatment). Panel C No

522 detectable enhancement of rifampin bactericidal activity by ML141 at concentrations tested.

523 Following treatment of $3 \times 10^{7}$ Staphylococcus aureus CFU with dimethyl sulfoxide (DMSO),

524 ML141 $(10 \mu \mathrm{M})$, rifampin $(0.002 \mathrm{mg} / \mathrm{L})$, or ML141 $(10 \mu \mathrm{M})$ in combination with rifampin

$525\left(0.002 \mathrm{mg} / \mathrm{L} ; 1 \mathrm{hr}, 37^{\circ} \mathrm{C}, 5 \% \mathrm{CO}_{2}\right)$, bacteria were plated and quantified as described above. Data

526 are represented by $\mathrm{CFU} / \mathrm{ml} \pm \mathrm{SEM}$ (* less than DMSO, $P<0.05$ by one-way ANOVA followed

527 by Holm-Sidak's post-hoc analysis, $\mathrm{n}=3 /$ treatment).

528

529 Figure 5 Analysis of simvastatin cotreatment with rifampin yields differential results from those

530 of ML141. Panel A Cotreatment of simvastatin with rifampin fails to improve rifampin efficacy. 
531 HEK 293-A cells were plated at $3 \times 10^{5}$ cells $/ \mathrm{ml}$ in $35 \mathrm{~mm}$ cell culture dishes. The following day,

532 HEK 293-A cells were treated with dimethyl sulfoxide (DMSO) or simvastatin (1 $\mu \mathrm{M} ; 24 \mathrm{hr}$,

$53337^{\circ} \mathrm{C}, 5 \% \mathrm{CO}_{2}$ ). The next day, HEK 293-A cells were infected with $3 \times 10^{7}$ Staphylococcus

534 aureus colony forming units $\left(\mathrm{CFU} ; 1 \mathrm{hr}, 37^{\circ} \mathrm{C}, 5 \% \mathrm{CO}_{2}\right)$ then were treated with DMSO,

535 simvastatin $(1 \mu \mathrm{M})$, rifampin $(0.01 \mathrm{mg} / \mathrm{L})$, or cotreatment of simvastatin $(1 \mu \mathrm{M})$ with rifampin

$536\left(0.01 \mathrm{mg} / \mathrm{L} ; 1 \mathrm{hr}, 37^{\circ} \mathrm{C}, 5 \% \mathrm{CO}_{2}\right)$. Extracellular bacteria were killed using gentamicin $(50$

$537 \mu \mathrm{g} / \mathrm{ml})$ and lysostaphin $\left(20 \mu \mathrm{g} / \mathrm{ml} ; 45 \mathrm{~min}, 37^{\circ} \mathrm{C}, 5 \% \mathrm{CO}_{2}\right)$ and intracellular $S$. aureus were

538 harvested using $1 \%$ saponin $\left(20 \mathrm{~min}, 37^{\circ} \mathrm{C}, 5 \% \mathrm{CO}_{2}\right)$. Serial dilutions were plated onto tryptic

539 soy agar $\left(24 \mathrm{hr}, 37^{\circ} \mathrm{C}\right)$ and colony counts were performed. Data are represented by $\mathrm{CFU} / \mathrm{ml} \pm$

540 SEM (* less than DMSO, $P<0.05$ by one-way ANOVA followed by Holm-Sidak's post-hoc

541 analysis, $\mathrm{n}=3$ /treatment). Data are pooled from two independent experiments. Panel B Increase

542 in HEK 293-A cell membrane permeability by simvastatin is reversed by cotreatment. HEK 293-

543 A cells were plated at $3 \times 10^{5}$ cells $/ \mathrm{ml}$ in $35 \mathrm{~mm}$ cell culture dishes. HEK 293-A cells were

544 treated with DMSO or simvastatin $\left(1 \mu \mathrm{M} ; 24 \mathrm{hr}, 37^{\circ} \mathrm{C}, 5 \% \mathrm{CO}_{2}\right)$. The next day, cells were

545 treated with DMSO, simvastatin $(1 \mu \mathrm{M})$, rifampin $(0.01 \mathrm{mg} / \mathrm{L})$, or cotreatment of simvastatin $(1$

$546 \mu \mathrm{M})$ and rifampin $\left(0.01 \mathrm{mg} / \mathrm{L} ; 1 \mathrm{hr}, 37^{\circ} \mathrm{C}, 5 \% \mathrm{CO}_{2}\right)$. HEK $293-\mathrm{A}$ cells were harvested and

547 resuspended in FACS buffer, then stained with propidium iodide (PI). Samples were analyzed

548 using a MACSQuant Analyzer 10 flow cytometer. Data are represented as percent $\mathrm{PI}^{+}$cells \pm

549 SEM (* greater than DMSO, rifampin, and simvastatin/rifampin cotreatment, $P<0.05$ by one-

550 way ANOVA followed by Holm-Sidak's post-hoc analysis, $n=3 /$ treatment). Panel C

551 Representative histogram demonstrates uptake of PI by simvastatin-treated HEK 293-A cells is

552 reversed by cotreatment with rifampin. Using MACSQuantify software, samples from PI-assay

553 were analyzed and representative histogram generated of distribution of HEK 293-A cells treated 
554 with DMSO (green), simvastatin (black), rifampin (purple), or rifampin with simvastatin as

555 cotreatment (red). Overlay of histograms reveals the highest peak is from simvastatin sample 556 and that the cotreatment peak is similar to that of DMSO.

557 


\section{Table 1 (on next page)}

Treatment regimen for cotreatment assays. 


\section{Treatment Group}

\begin{tabular}{|c|c|c|c|c|}
\hline & \multicolumn{4}{|c|}{ Treatment Group } \\
\hline & DMSO & $\begin{array}{l}\text { ML141 or } \\
\text { simvastatin }\end{array}$ & Rifampin & $\begin{array}{l}\text { ML141/rifampin or } \\
\text { simvastatin/rifampin }\end{array}$ \\
\hline $\begin{array}{l}\text { Pre-treatment } \\
\qquad(24 \mathrm{hr})\end{array}$ & DMSO & $\begin{array}{l}\text { ML141 or } \\
\text { simvastatin }\end{array}$ & DMSO & $\begin{array}{l}\text { ML141 or } \\
\text { simvastatin }\end{array}$ \\
\hline $\begin{array}{l}\text { Inoculation } \\
\text { (30 min) }\end{array}$ & $3 \times 10^{7} \mathrm{CFU}$ & $3 \times 10^{7} \mathrm{CFU}$ & $3 \times 10^{7} \mathrm{CFU}$ & $3 \times 10^{7} \mathrm{CFU}$ \\
\hline $\begin{array}{l}\text { Post-treatment } \\
(1 \mathrm{hr})\end{array}$ & DMSO & $\begin{array}{l}\text { ML141 or } \\
\text { simvastatin }\end{array}$ & Rifampin & $\begin{array}{l}\text { ML141/rifampin or } \\
\text { simvastatin/rifampin }\end{array}$ \\
\hline
\end{tabular}

1

2 Table 1. Treatment regimen for cotreatment assays. 


\section{Figure 1}

A higher concentration of rifampin is required when there is an increase in the bacterial load.

(A) HEK 293-A cells were plated at $3 \times 10^{5}$ cells $/ \mathrm{ml}$ in $35 \mathrm{~mm}$ cell culture dishes. Two days later, cells were infected at a multiplicity of infection (MOI) of $2\left(6 \times 10^{5}\right.$ Staphylococcus aureus colony forming units; $\mathrm{CFU} ; 30 \mathrm{~min}, 37^{\circ} \mathrm{C}, 5 \% \mathrm{CO}_{2}$ ) then treated with dimethyl sulfoxide (DMSO), or $0.001,0.003,0.01$, or $0.03 \mathrm{mg} / \mathrm{L}$ rifampin $\left(1 \mathrm{hr}, 37^{\circ} \mathrm{C}, 5 \% \mathrm{CO}_{2}\right)$. HEK 293-A cells were treated with gentamicin $(50 \mu \mathrm{g} / \mathrm{ml})$ and lysostaphin $\left(20 \mu \mathrm{g} / \mathrm{ml} ; 45 \mathrm{~min}, 37^{\circ} \mathrm{C}, 5 \% \mathrm{CO}_{2}\right)$ to remove extracellular bacteria and intracellular bacteria were harvested using $1 \%$ saponin (20 $\mathrm{min}, 37^{\circ} \mathrm{C}, 5 \% \mathrm{CO}_{2}$ ). Serial dilutions were plated on tryptic soy agar $\left(24 \mathrm{hr}, 37^{\circ} \mathrm{C}\right.$ ) and colony counts were performed. Data are pooled from two independent experiments and are represented as CFU/ml \pm SEM ( $n=4-8 /$ treatment). (B) HEK 293-A cells were plated as described above and infected at MOI of $100\left(3 \times 10^{7} \mathrm{CFU} ; 1 \mathrm{hr}, 37^{\circ} \mathrm{C}, 5 \% \mathrm{CO}_{2}\right)$. HEK 293-A cells were treated with DMSO, or $0.003,0.01,0.03$, or $0.1 \mathrm{mg} / \mathrm{L}$ rifampin $\left(1 \mathrm{hr}, 37^{\circ} \mathrm{C}, 5 \%\right.$ $\mathrm{CO}_{2}$ ). Extracellular bacteria were killed, intracellular bacteria harvested, and $\mathrm{CFU} / \mathrm{ml}$ determined as described above. Data are represented as CFU/mI \pm SEM $(n=4 /$ treatment). 
A
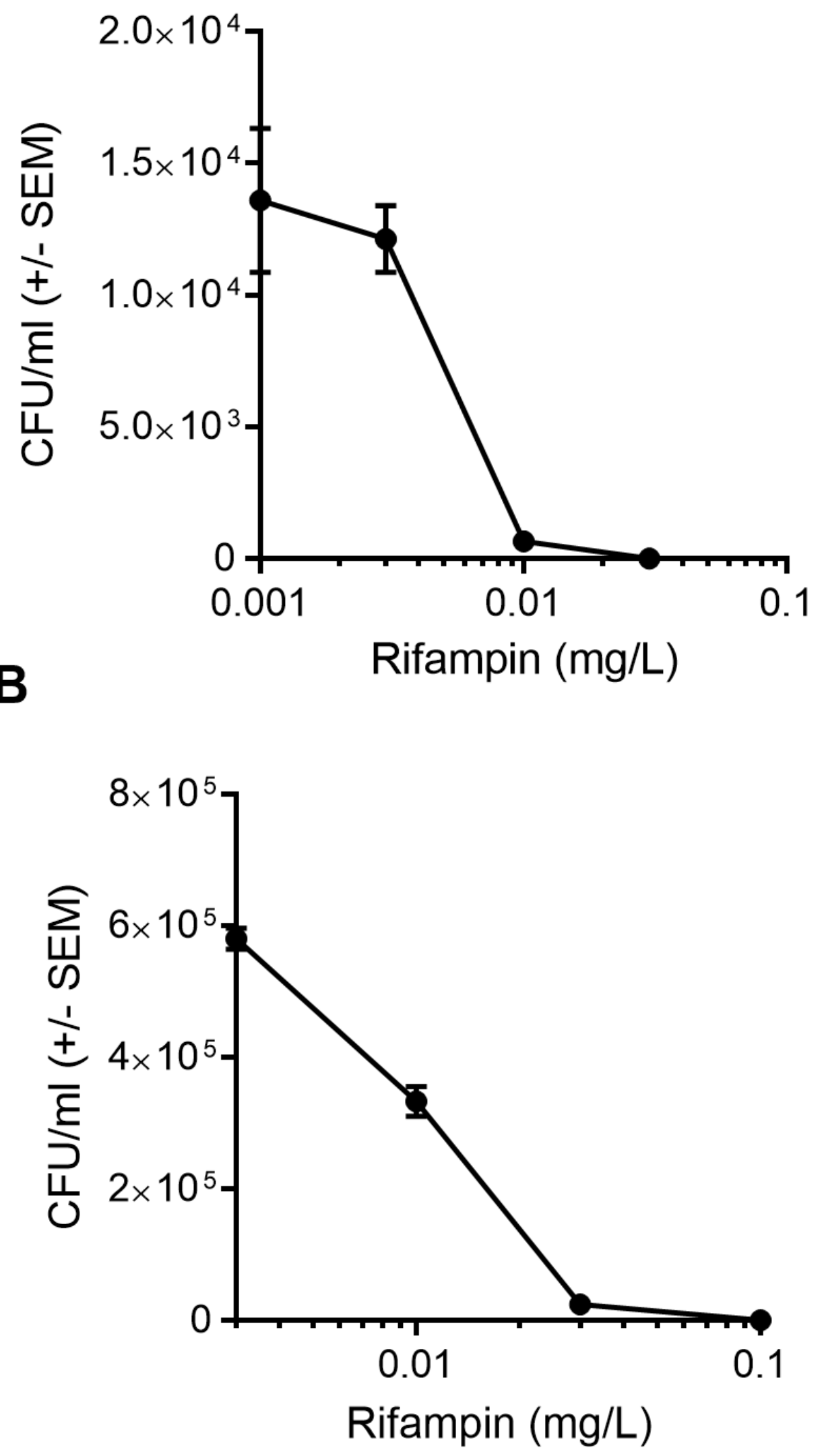


\section{Figure 2}

Pretreatment with ML141 and cotreatment of ML141 with rifampin reduces intracellular Staphylococcus aureus infection.

(A) HEK 293-A cells were plated at $3 \times 10^{5}$ cells $/ \mathrm{ml}$ in $35 \mathrm{~mm}$ cell culture dishes. The following day, cells were treated with dimethyl sulfoxide (DMSO) or ML141 (10 $\mu \mathrm{M} ; 24 \mathrm{hr}$, $37^{\circ} \mathrm{C}, 5 \% \mathrm{CO}_{2}$ ). HEK 293-A cells were infected at a multiplicity of infection (MOI) of 2 (30 min, $\left.37^{\circ} \mathrm{C}, 5 \% \mathrm{CO}_{2}\right)$ then were treated with gentamicin $(50 \mu \mathrm{g} / \mathrm{ml})$ and lysostaphin $(20 \mu \mathrm{g} / \mathrm{ml} ; 45$ $\min , 37^{\circ} \mathrm{C}, 5 \% \mathrm{CO}_{2}$ ) to remove extracellular bacteria. Intracellular bacteria were harvested using $1 \%$ saponin $\left(20 \mathrm{~min}, 37^{\circ} \mathrm{C}, 5 \% \mathrm{CO}_{2}\right.$ ) and serial dilutions were plated on tryptic soy agar $\left(24 \mathrm{hr}, 37^{\circ} \mathrm{C}\right)$. Intracellular bacteria were quantified by colony counts. Data are represented as colony forming units (CFU)/ml \pm SEM (* less than DMSO, $P<0.05$ by Student's t-test, $n=4 /$ treatment). (B) HEK 293-A cells were plated and pretreated with ML141 or DMSO as described above. HEK 293-A cells were infected at MOI of 100 by incubating with $3 \times 10^{7} \mathrm{~S}$. aureus CFU then were treated with DMSO, ML141 $(10 \mu \mathrm{M})$, rifampin $(0.01 \mathrm{mg} / \mathrm{L})$, or cotreatment of ML141 $(10 \mu \mathrm{M})$ with rifampin $\left(0.01 \mathrm{mg} / \mathrm{L} ; 1 \mathrm{hr}, 37^{\circ} \mathrm{C}, 5 \%\right.$ CO2). Extracellular bacteria were killed, and intracellular bacteria were harvested and plated as described above. Data are represented by CFU/ml \pm SEM (* less than DMSO and ML141, ** less than DMSO, ML141, or rifampin, $P<0.05$ by one-way ANOVA followed by Holm-Sidak's post-hoc analysis, $n=4$ /treatment). Data are representative of three replicate experiments. 
A
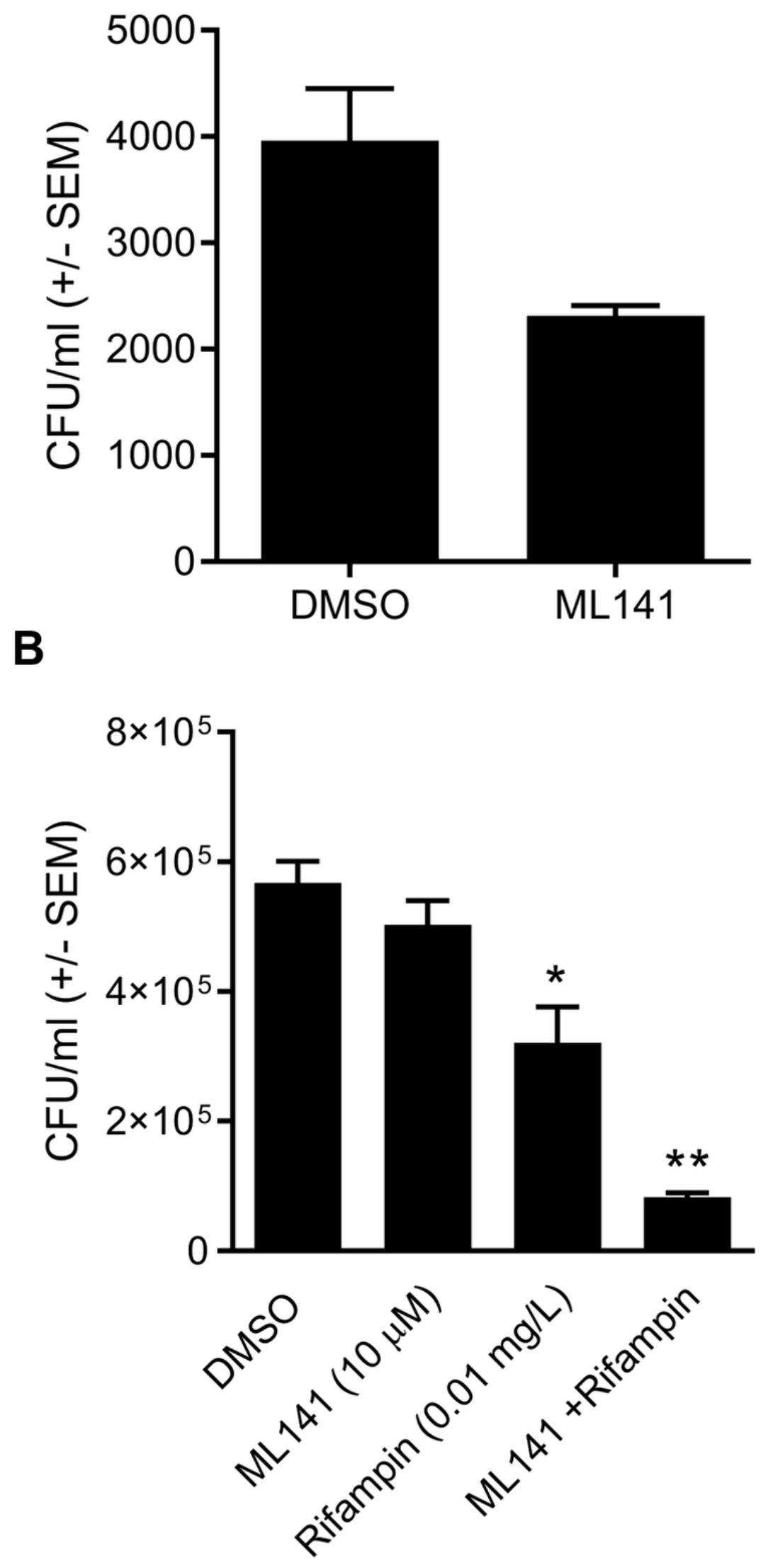


\section{Figure 3}

HEK 293-A cell viability and membrane integrity are maintained following cotreatment of ML141 with rifampin.

(A) HEK 293-A cells were plated at $5 \times 10^{4}$ cells/well in a 48-well plate. The following day, cells were treated with dimethyl sulfoxide (DMSO), ML141 $(10 \mu \mathrm{M})$, rifampin $(0.01 \mathrm{mg} / \mathrm{L})$, or cotreatment of ML141 $(10 \mu \mathrm{M})$ and rifampin $\left(0.01 \mathrm{mg} / \mathrm{L} ; 24 \mathrm{hr}, 37^{\circ} \mathrm{C}, 5 \% \mathrm{CO}_{2}\right)$. Host cell viability was quantified following incubation with the CellTiter $96 \AA$ AQueous One Solution Reagent $\left(1 \mathrm{hr}, 37^{\circ} \mathrm{C}, 5 \% \mathrm{CO}_{2}\right)$. Absorbance was measured at $490 \mathrm{~nm}$ using a BioRad iMark Microplate Reader. Data are represented as absorbance \pm SEM $(P>0.05$ by one-way ANOVA followed by Holm-Sidak's post-hoc analysis, $n=4$ /treatment). (B) HEK 293-A cells were plated at $3 \times 10^{5} \mathrm{cells} / \mathrm{ml}$ in $35 \mathrm{~mm}$ cell culture dishes. HEK 293-A cells were treated with dimethyl sulfoxide (DMSO) or ML141 $\left(10 \mu \mathrm{M} ; 24 \mathrm{hr}, 37^{\circ} \mathrm{C}, 5 \% \mathrm{CO}_{2}\right)$. The next day, cells were treated with DMSO, ML141 $(10 \mu \mathrm{M})$, rifampin $(0.01 \mathrm{mg} / \mathrm{L})$, or cotreatment of ML141 $(10 \mu \mathrm{M})$ and rifampin $\left(0.01 \mathrm{mg} / \mathrm{L} ; 1 \mathrm{hr}, 37^{\circ} \mathrm{C}, 5 \% \mathrm{CO}_{2}\right)$. HEK 293-A cells were harvested and resuspended in FACS buffer, then stained with propidium iodide (PI). Samples were analyzed using a MACSQuant Analyzer 10 flow cytometer. Data are represented as percent $\mathrm{PI}^{+}$cells \pm SEM ( $P>0.05$ by one-way ANOVA followed by Holm-Sidak's post-hoc analysis, $\mathrm{n}=$ 3/treatment). Data are pooled from two independent experiments. (C) Representative histogram from PI assay indicates similar levels of PI uptake by HEK 293-A cells treated with DMSO (green), ML141 (black), rifampin (purple), or rifampin with ML141 as cotreatment (red). The overlay of histograms reveals nearly overlapping peaks for each treatment. 

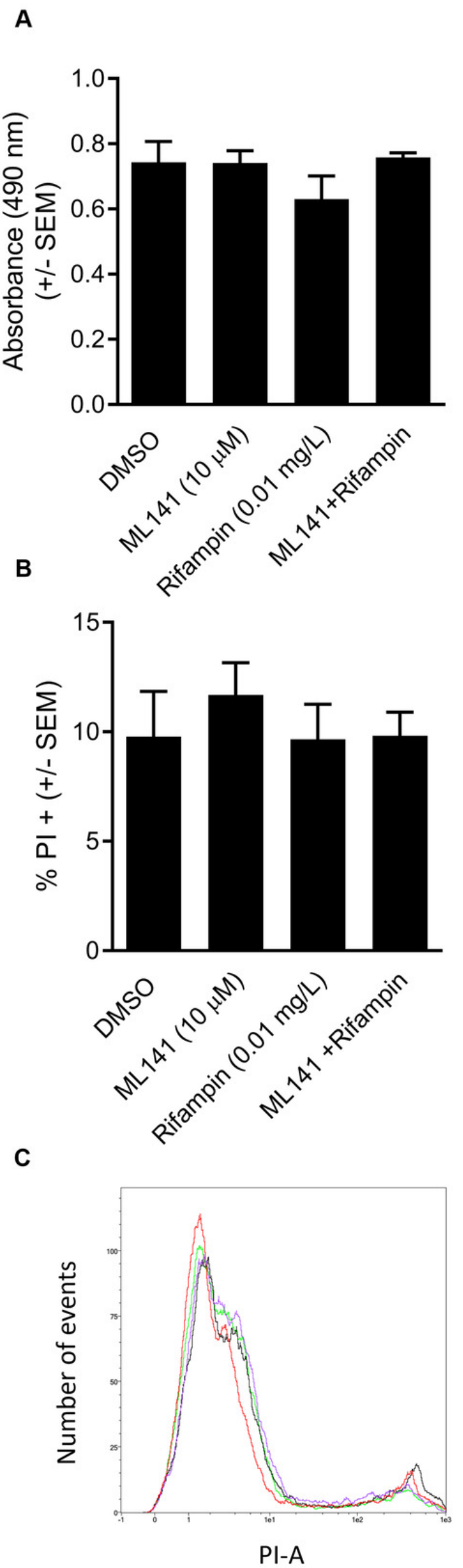

Peer) reviewing PDF | (2020:06:50566:2:0:NEW 11 Oct 2020) 


\section{Figure 4}

Rifampin bactericidal activity is not enhanced by ML141.

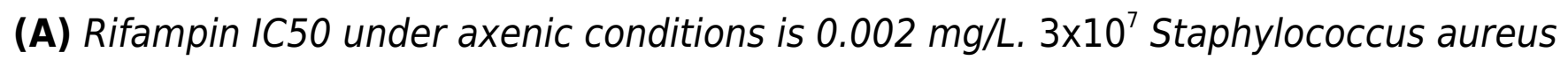
colony forming units (CFU) were incubated with increasing concentrations of rifampin or dimethyl sulfoxide (DMSO; $1 \mathrm{hr}, 37^{\circ} \mathrm{C}, 5 \% \mathrm{CO}_{2}$ ). Serial dilutions were plated on tryptic soy agar $\left(24 \mathrm{hr}, 37^{\circ} \mathrm{C}\right)$ and colony counts were performed. Data are represented as CFU/ml \pm SEM ( $\mathrm{n}=3 /$ treatment). (B) ML141 bactericidal activity not detected at concentrations used. Following treatment of $3 \times 10^{7}$ Staphylococcus aureus colony forming units (CFU) with dimethyl sulfoxide (DMSO) or ML141 $\left(10 \mu \mathrm{M} ; 1 \mathrm{hr}, 37^{\circ} \mathrm{C}, 5 \% \mathrm{CO}_{2}\right)$, serial dilutions were plated onto tryptic soy agar $\left(24 \mathrm{hr}, 37^{\circ} \mathrm{C}\right)$ and colony counts were performed. Data are represented by $\mathrm{CFU} / \mathrm{ml} \pm \mathrm{SEM}$ ( $P>0.05$ by one-way ANOVA followed by Holm-Sidak's posthoc analysis, $n=3 /$ treatment). (C) No detectable enhancement of rifampin bactericidal activity by ML141 at concentrations tested. Following treatment of $3 \times 10^{7}$ Staphylococcus aureus CFU with dimethyl sulfoxide (DMSO), ML141 (10 $\mu \mathrm{M})$, rifampin (0.002 mg/L), or ML141 $(10 \mu \mathrm{M})$ in combination with rifampin $\left(0.002 \mathrm{mg} / \mathrm{L} ; 1 \mathrm{hr}, 37^{\circ} \mathrm{C}, 5 \% \mathrm{CO}_{2}\right)$, bacteria were plated and quantified as described above. Data are represented by CFU/mI \pm SEM (* less than DMSO, $P<0.05$ by one-way ANOVA followed by Holm-Sidak's post-hoc analysis, $\mathrm{n}=$ $3 /$ treatment). 
A

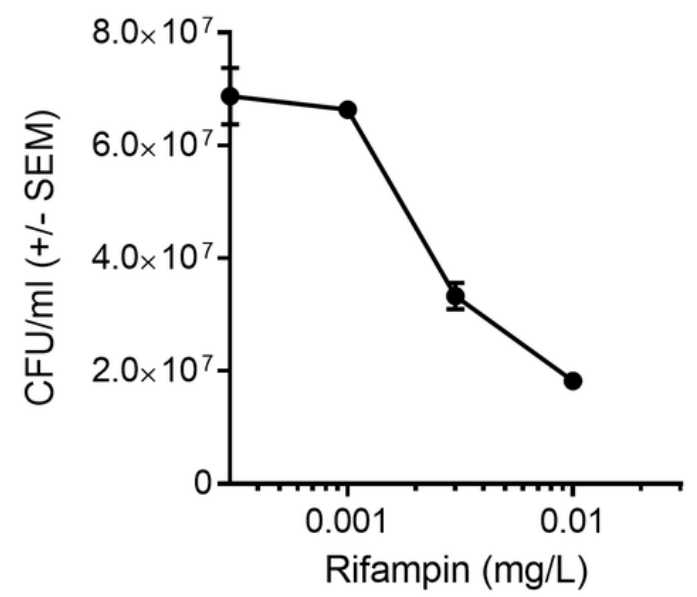

B
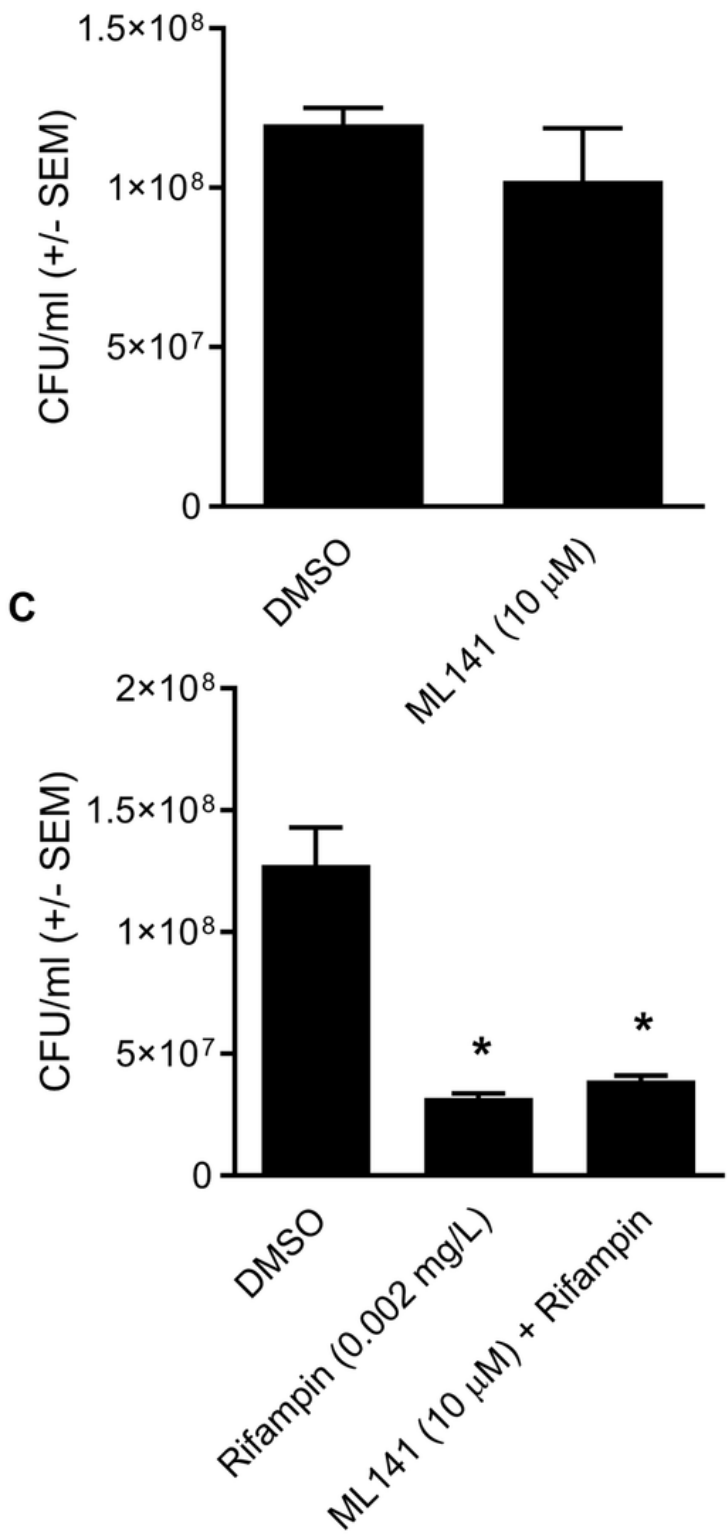


\section{Figure 5}

Analysis of simvastatin cotreatment with rifampin yields differential results from those of ML141.

(A) Cotreatment of simvastatin with rifampin fails to improve rifampin efficacy. HEK 293-A cells were plated at $3 \times 10^{5}$ cells $/ \mathrm{ml}$ in $35 \mathrm{~mm}$ cell culture dishes. The following day, HEK 293A cells were treated with dimethyl sulfoxide (DMSO) or simvastatin $\left(1 \mu \mathrm{M} ; 24 \mathrm{hr}, 37^{\circ} \mathrm{C}, 5 \%\right.$ $\left.\mathrm{CO}_{2}\right)$. The next day, HEK 293-A cells were infected with $3 \times 10^{7}$ Staphylococcus aureus colony forming units (CFU; $1 \mathrm{hr}, 37^{\circ} \mathrm{C}, 5 \% \mathrm{CO}_{2}$ ) then were treated with DMSO, simvastatin $(1 \mu \mathrm{M})$, rifampin $(0.01 \mathrm{mg} / \mathrm{L})$, or cotreatment of simvastatin $(1 \mu \mathrm{M})$ with rifampin $(0.01 \mathrm{mg} / \mathrm{L} ; 1 \mathrm{hr}$, $\left.37^{\circ} \mathrm{C}, 5 \% \mathrm{CO}_{2}\right)$. Extracellular bacteria were killed using gentamicin $(50 \mu \mathrm{g} / \mathrm{ml})$ and lysostaphin $\left(20 \mu \mathrm{g} / \mathrm{ml} ; 45 \mathrm{~min}, 37^{\circ} \mathrm{C}, 5 \% \mathrm{CO}_{2}\right)$ and intracellular $S$. aureus were harvested using $1 \%$ saponin $\left(20 \mathrm{~min}, 37^{\circ} \mathrm{C}, 5 \% \mathrm{CO}_{2}\right.$ ). Serial dilutions were plated onto tryptic soy agar $\left(24 \mathrm{hr}, 37^{\circ} \mathrm{C}\right.$ ) and colony counts were performed. Data are represented by CFU/ml $\pm \mathrm{SEM}$ (* less than DMSO, $P<0.05$ by one-way ANOVA followed by Holm-Sidak's post-hoc analysis, $\mathrm{n}$ $=3 /$ treatment). Data are pooled from two independent experiments. (B) Increase in HEK 293-A cell membrane permeability by simvastatin is reversed by cotreatment. HEK 293-A cells were plated at $3 \times 10^{5}$ cells $/ \mathrm{ml}$ in $35 \mathrm{~mm}$ cell culture dishes. HEK 293-A cells were treated with DMSO or simvastatin $\left(1 \mu \mathrm{M} ; 24 \mathrm{hr}, 37^{\circ} \mathrm{C}, 5 \% \mathrm{CO}_{2}\right)$. The next day, cells were treated with DMSO, simvastatin $(1 \mu \mathrm{M})$, rifampin $(0.01 \mathrm{mg} / \mathrm{L})$, or cotreatment of simvastatin $(1 \mu \mathrm{M})$ and rifampin $\left(0.01 \mathrm{mg} / \mathrm{L} ; 1 \mathrm{hr}, 37^{\circ} \mathrm{C}, 5 \% \mathrm{CO}_{2}\right)$. HEK 293-A cells were harvested and resuspended in FACS buffer, then stained with propidium iodide (PI). Samples were analyzed using a MACSQuant Analyzer 10 flow cytometer. Data are represented as percent $\mathrm{Pl}^{+}$cells \pm SEM (* greater than DMSO, rifampin, and simvastatin/rifampin cotreatment, $P<0.05$ by one- 
way ANOVA followed by Holm-Sidak's post-hoc analysis, $n=3 /$ treatment). (C) Representative histogram demonstrates uptake of PI by simvastatin-treated HEK 293-A cells is reversed by cotreatment with rifampin. Using MACSQuantify software, samples from PIassay were analyzed and representative histogram generated of distribution of HEK 293-A cells treated with DMSO (green), simvastatin (black), rifampin (purple), or rifampin with simvastatin as cotreatment (red). Overlay of histograms reveals the highest peak is from simvastatin sample and that the cotreatment peak is similar to that of DMSO. 
A
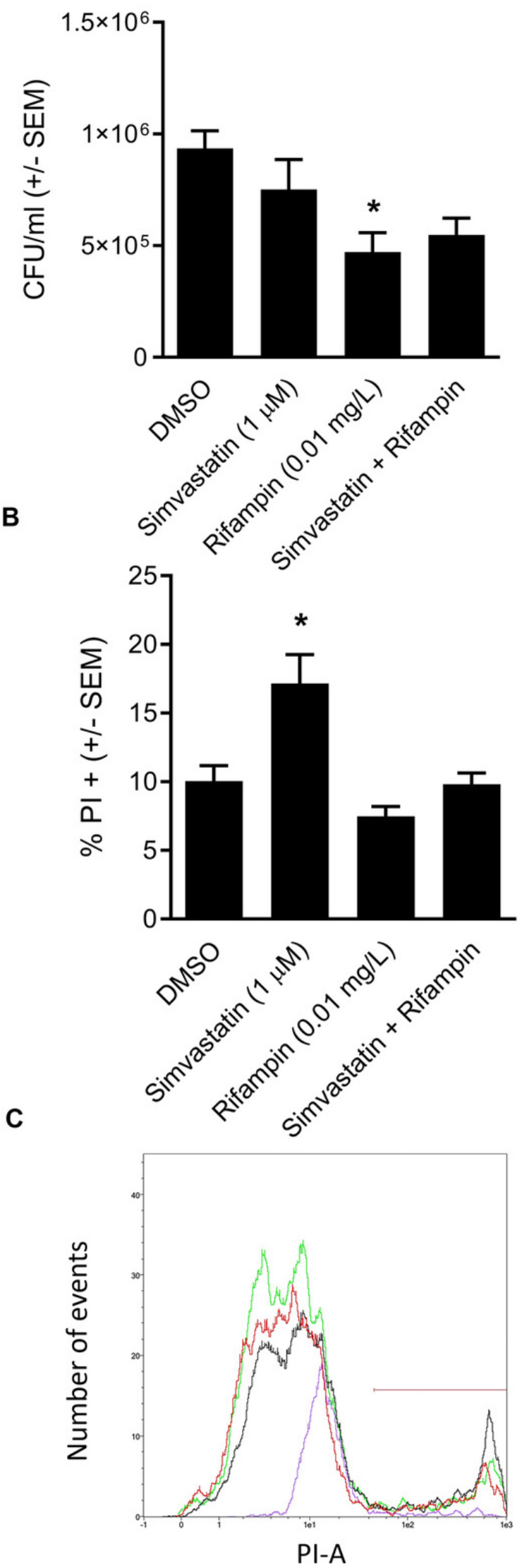

Peer) reviewing PDF | (2020:06:50566:2:0:NEW 11 Oct 2020) 